BFFECTS OF HUMAN PANCREATIC GROWTH HORMONE RELEASING HORMONE (HPGRH) ON GROWTH HORMONE (GH) SECRETION IN PREGNANT AND FETAL RATS. D.Shulman, G. Duckett, M. Sweetland, A. Root. Dept. of Pediatrics, Univ. of So. Floxida Coll. of Med., All Children's Hosp., St. Petersburg, F1. Pregnant Holtzman rats were studied at 19 and 20 days gestation. Animals were anesthetized at $-30 \mathrm{~min}$ with pentobarbitol $60 \mathrm{mg} / \mathrm{kg}$ IP. 5 ug HPGRH $1-44$ or normal 1 saline was pentobitol 17 at 0 min. Blod for maternal $\mathrm{GH}$ measurement was administered $1 \mathrm{at} 0$ min. Blood for maternal obtained via cardiac puncture at min and following at 11 min. Fetuses were removed by C-section between 7 and fetal min and cardiac blood from litterma Maternal GH** Treatment $\mathrm{GH}^{* *}$. $\frac{\text { Gestational Age }}{19 \text { days }(\mathrm{N}=4)} \frac{\text { Treatine }}{\text { Saline }} 546+246 * \rightarrow 362+106$

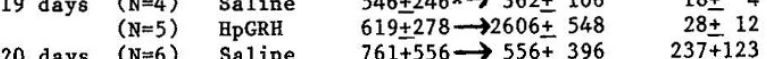
$(\mathrm{N}=6) \quad$ Saline $\quad 761 \pm 556 \rightarrow 556 \pm 396 \quad 237 \pm 123$ $(N=6)$ HpGRH $591 \pm 627 \rightarrow 1797 \pm 413 \quad 141 \pm 55$ Mean maternal $\mathrm{GH}$ levels rose significantly $(\mathrm{p}<0.005)$ in anim receiving HPGRH and were unchanged in those receiving saline. Mean fetal GH levels were significantly greater $(p<0.005)$ at
vs 19 days gestation. There were no significant differences between mean fetal GH concentrations of mothers receiving HPGRH and those receiving saline. HPGRH increases GB concentrations in the pregnant rat. HPGRH administration to the pregnant rat during late gestation does not increase $\mathrm{GH}$ concentrations in the fetus suggesting either that HPGRH does not cross the rat placenta or that the fetal rat pituitary is insensitive to HPGRH at this dosage.

EFFECT OF HYPERTHYROIDISM UPON HUMAN PANCREATIC

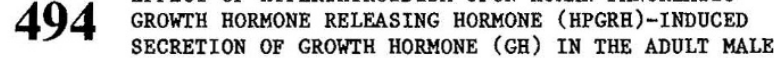
RAT. D. Shulman, G. Duckett, $\underline{M}$. Sweetland, J. Strzelecki, A. Root, Dept. of Peds., Univ. of So. Florida College of Medicine, A11 Children's Hospital, St. Petersburg, FI.

Four groups $(n=8)$ of $300 \mathrm{~g}$ male rats received daily s.c. injections of saline, thyroxine (T4) 20 ug, T4 40 ug, or T4 80 ug for 14 days. $24 \mathrm{hrs}$ following the 1ast injection rat s were anesthetized with pentobarbital (IP $50 \mathrm{mg} / \mathrm{kg}$ ) at $-30 \mathrm{~min}$. $10 \mathrm{ug}$ anesthetized with pentobarbital (IP $50 \mathrm{mg} / \mathrm{kg}$ ) at -30 min determination was obtained via cardiac puncture at 0,5 and 10 min. Rats were decapitated at 15 min; trunk blood was collected for measurement of $\mathrm{GH}$, T4RIA, and T3RIA Group Treatment $\frac{\mathrm{T} 4(\mathrm{ug} / \mathrm{d} 1)}{4+1^{*}} \frac{\mathrm{T} 3 \mathrm{RIA}(\mathrm{ng} / \mathrm{d} 1)}{34 \pm 8^{*}}$ $\begin{array}{llll}A & \text { Saline } & 4 \pm 1^{*} & 34 \pm 8 \\ \text { B } & \text { T4 20ug } & 12 \pm 2 & 84 \pm 16\end{array}$ C T4 40ug $15 \pm 2 \quad 201 \pm 36$

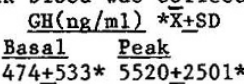
$188 \pm 106 \quad 5495+1668$ $188+143 \quad 5211+1600$ $224+98 \quad 4701 \pm 1168$ Average daily food intake was significantly greater in groups C Average daily food intake was significantly greater in groups and $D$ than in group $A(P<.05)$. Final mean body wgt varied
inversely with the $T 4$ treatment dosage (Groups $C, D<A ; P<.01)$. T4RIA and T3RIA concentrations were significantly greater in rats treated with $T 4$ then in control rats $(p<.001)$. There were no statistical differences between mean basal or peak $\mathrm{GH}$ responses to HPGRH among any of the groups.

Hyperthyroidism of brief duration does not alter the $\mathrm{GH}$ secretory response to a pharmacologic dose of HPGRH in the adult male rat.

\section{$\dagger 495$}

GROWTH HORMONE NEUROSECRETORY DYSFUNCTION (GHND) IN THE SPECTRUM OF ENDOCRINE ABNORMALITIES IN CHILDREN WITH EMPTY SELLA. D. Shulman, A. Vargas, A. Root, C.Martinez, B.B.Bercu, Dept. of Pediatrics, Univ. of South Florida Co11. of Med., A11 Children's Hospital., St. Petersburg, F1. We examined 5 children with radiologic evidence of empty sella (patients 1-3) or partially empty sella (pts 4-5). Reasons for hyporrathyro (HPT). pituitary axis including provocative tests of TSH, PRL,LH,FSH, GH pituitary axis including provocative tests of TSH, PR $\frac{\text { Pts }}{1(13.2 \mathrm{yM})} \frac{\text { Bone age }}{15 \mathrm{y}} \frac{\text { Diagnosis }}{\text { HPT }} \frac{\text { Pit. studies-peak (test) }}{\text { No abnormalities }}$ $2(16.9 \mathrm{yF}) \quad 11-12 \mathrm{y}$ SS $\quad$ GH $-2.1 \mathrm{ng} / \mathrm{ml}$ (L-DOPA,ITT, clonidine),PRL-2.0 ng/mi' (TRH) $\mathrm{LH}-5.5 \mathrm{mIU} / \mathrm{m} 1$ (LHRH)

$3(11 \mathrm{yF}) \quad 8-9 \mathrm{y} \quad$ SS $\quad$ No abnormalities $\begin{array}{llll}4(13 \mathrm{yM}) & 9 \mathrm{y} & \text { SS } & \text { No abnormalities } \\ 5(7.8 \mathrm{yF}) & 10-11 \mathrm{y} & \text { PP } & \text { Not }\end{array}$ Classic GH deficiency was observed in pt 2 . Normal provocative tests were observed in pts 3 and 4 . Because of poor growth velocities, delayed bone ages and normal provocative tests, $24 \mathrm{hr}$ velocities, delayed bone ages and normal provocative tests, $24 \mathrm{hr}$
GH output was measured in the latter two pts. Mean $24 \mathrm{hr}$ GH leve GH output was measured in the latter two pts. Mean $24 \mathrm{hr} G H$ level
in pt 3 was $1.0 \pm 0.0 \mathrm{ng} / \mathrm{ml}(\overline{\mathrm{X}}+\mathrm{SE})$ with no significant $(\geq 5 \mathrm{ng} / \mathrm{ml})$ GH pulses observed. Mean $24 \mathrm{hr}$ GH level in pt 4 was $2.0 \pm 0.4$ $\mathrm{ng} / \mathrm{ml}$ with only one significant pulse (peak $=21 \mathrm{ng} / \mathrm{ml}$ ) occuring at night. These results are low and consistent with GHND. Empty sella in childhood is associated with a spectrum of hypothalamic-pituitary abnormalities now including GHND.
PULSATILE GROWTH HORMONE (GH) SECRETION DURING

496 PUBERTAL DEVELOPMENT IN INTACT AND CASTRATE MONKEYS. B.E. Spiliotis, A.W.Root,, C-S. Hu, and B.B. Bercu Pregnancy Research Branch, NICHD, NIH and All Children's Hospital, University of South Florida, St. Petersburg, F1. To assess whether pulsatile GH secretion changes during pubertal development, 23 intact and 21 castrate male macaques (rhesus and cynomologous) from prepubertal through adult life were evaluated. Blood was withdrawn at 15 min intervals for 12 or $24 \mathrm{hr}$ through a femoral venous catheter. All animals were fit with a mobile vest and tether assembly. Pubertal development was assessed on the basis of chronological age, gonadotropin and testosterone secretion, testicular volume, hCG challenge tests and skeletal age. The pulsatile secretory $\mathrm{GH}$ data are summarized below:

Developmental age $\bar{x}$ GH conc $\bar{x}$ peak GH conc No. GH pulses Pntact Pubertal $(n=6)$

Adult $(n=14)$

Castrate

Prepubertal $(n=3)$ Pubertal $(n=3)$
Aduit $(n=15)$ $(\mathrm{ng} / \mathrm{ml})$ $\frac{(\mathrm{ng} / \mathrm{ml})}{8.5 \pm 3.0}$ $\frac{\begin{array}{c}\overline{\mathrm{x}} \text { peak GH conc } \\ (\mathrm{ng} / \mathrm{ml})\end{array}}{17 \pm 3} \geqslant \frac{\begin{array}{c}\text { No. GH pulses } \\ 18 \pm 2\end{array}}{20 \mathrm{ng} / \mathrm{ml} / 12 \mathrm{hr}}$ $7.7 \pm 1.0$ $20 \pm 2$

$7.0 \pm 4.7$

$7.3 \pm 3.5$
$5.7 \pm 0.9$

$14 \pm 6$
$15+5$

$15 \pm 5$
$17 \pm 3$

$4 \pm 2$ $4 \pm 1$

These data suggest that pulsatile GH secretion does not change significant1y during pubertal development in male monkeys and that endogenous testosterone does not alter pulsatile $\mathrm{GH}$ secretion.

\section{7} FETAL CIRCADTAN RHYTHMS: CYCLES OF VASOPRESSIN (VP) LEVELS IN CRREBROSPINAL FLUID (CSF) NOT BLOOD. Raymond I。 Stark, Salha S. Danie1, M. Kazim Husain, Henry R。Rey and $L_{0}$ Stanley James。 Col1. of P\&S, Columbia U. Depts。 of Pediat, \& Anestho Presbyterian Hospital, No $\mathrm{Y}_{0} \mathrm{C}$. Besides classical effects on water balance and blood pressure, vasopressin has important functions in brain including modulation of behavioral processes and memory consolidation. In adult animals immunoactive VP in CSF exhibits a circadian pattern of release suggesting that the CSF may be a condult for the effects of VP on diverse brain areas. To characterize the release of VP by the fetus, CSF was withdrawn continuously $(1.0 \mathrm{~m} 1 / \mathrm{hr} \times 3$ days $)$ from the prechaismatic fossa of 5 chronically instrumented fetal sheep at 108 to $146 \mathrm{~d}$ gestation in 7 studies and plasma sampled intermittently $(1.5 \mathrm{ml} \mathrm{q} 4 \mathrm{~h} \mathrm{X}$ 1 day) in 3 studies. Using a specific VP RIA, daily rhythms of VP in CSF were found for each fetus. Temporal profiles showed low levels of VP (12-25 pg/m1) during daylight alternating with high levels at night $(30-45 \mathrm{pg} / \mathrm{mI})$. Cycle length by frequency domain analysis was 22 to $24 \mathrm{hrs}$ 。 No similar frequency domain analysis was 22 to $24 \mathrm{hrs}$ 。 No similar The amplitude of the CSF rhythms was increased $(125 \mathrm{pg} / \mathrm{ml})$ with chronic hypoxia, acute hemorrhage and in the days immediately preceding term delivery。

We conclude that circadian rhythms of VP concentration in CSF but not plasma are present in the fetus during the final $25 \%$ of gestation. Changes in the amplitude and/or period of these rhythms may be important in the timing of parturition and the fetal response to suboptimal intrauterine condition.
TREATMENT OF TRUE PRECOCIOUS PUBERTY (TPP) WITH AN

498 INTRANASAL (IN) LUTEINIZING HORMONE RELEASING FACTOR (LRF) AGONIST (A). David K. Stephure, Bernard L. Silverman, Felix A. Conte, Stephen M. Rosenthal, Selna L. Kaplan, Melvin M. Grumbach. University

Peds, San Francisco, CA.
Potent LRF Agonists administered subcutaneously (SC) or IN have proven useful in the treatment of TPP. We studied a new LRFA, D Na16 LRF (Nafarelin acetate (NA), Syntex) in 7 girls (age $2-7 y$ ) and 2 boys (age 8-9y) with TPP (treatment duration 1.5-6 months (M)). NA $2 \mu \mathrm{g} / \mathrm{kg}$ was given SC OD for 2 weeks (W) and $400 \mu \mathrm{g}$ IN OD thereaf ter. Plasma NA was measured by RIA after the first

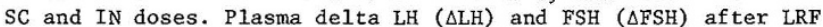
$100 \mathrm{ug}$ IV, estradiol (E2) and testosterone (T) were measured at baseline, $6 \mathrm{~W}$ and $3 \mathrm{M}$ intervals thereaf ter. Results are summarized below as mean \pm SEM (paired $t$ test): at $6 \mathrm{~W}, \Delta \mathrm{LH} 2.3 \pm 0.6 \mathrm{ng} / \mathrm{ml}$ $(\mathrm{p}<0.02), \triangle \mathrm{FSH} 0.7 \pm 0.2 \mathrm{ng} / \mathrm{ml}(\mathrm{p}<0.01), \mathrm{E}_{2} 23 \pm 7 \mathrm{pg} / \mathrm{ml}(\mathrm{p}<0.04), \mathrm{T}$ $36 \mathrm{ng} / \mathrm{dl}(\mathrm{n}=2)$; at $3 \mathrm{M}, \Delta \mathrm{LH} 1.4 \pm 0.2 \mathrm{ng} / \mathrm{ml} \quad(\mathrm{p}=0.05), \Delta \mathrm{FSH} 0.3 \pm 0.2$ $\mathrm{ng} / \mathrm{ml}(\mathrm{p}=0.025), \mathrm{E}_{2} 10 \mathrm{pg} / \mathrm{ml}(\mathrm{n}=2), \mathrm{T} 7 \mathrm{ng} / \mathrm{d} 1 \quad(\mathrm{n}=2)$ compared to baseline $\Delta \mathrm{LH} 10.2 \pm 3.6 \mathrm{ng} / \mathrm{ml}, \triangle \mathrm{FSH} 3.7 \pm 1.1 \mathrm{ng} / \mathrm{ml}, \mathrm{E}_{2} 53 \pm 12 \mathrm{pg} / \mathrm{ml}$ and T $373 n g / d 1(n=2)$. Plasma NA levels peaked 20 min after SC NA $(3.34 \pm 0.2 \mathrm{ng} / \mathrm{m} 1)$ and IN NA $(1.88 \pm 0.7 \mathrm{ng} / \mathrm{m} 1)$ and were measurable $(>0.05 \mathrm{ng} / \mathrm{ml})$ 8h after SC NA ( $9 / 9$ patients) and IN NA $(7 / 9) .6 / 7$ irls had menses in the first $M$ on treatment; however, no further girls had menses in the first $M$ on treatment; however, no furth
vaginal bleeding has occurred. Growth velocity decreased from $11.7 \mathrm{~cm} / \mathrm{y}$ before treatment to $6 \mathrm{~cm} / \mathrm{y}$ after $6 \mathrm{M}(\mathrm{n}=3)$.

Preliminary results suggest IN D Na1 ${ }^{6}$ LRF is an effective treatment for TPP in children. 